\title{
A VÁLLALATI INNOVÁCIÓ ÁLTAL INDUKÁLT SZERVEZETI VÁLTOZÁSOK A MAGYAR ENERGIASZEKTORBAN
}

A kutatás célja, hogy a globális energiaszektor átalakulásából következő megújulási kényszerben lévő magyarországi energetikai nagyvállalatok innovációmenedzsment-kihívásait azonosítsa, illetve összefüggéseket keressen az innováció gyakorlati megvalósítása és a szervezeti változás, változásvezetés szükségessége között. A kutatás induktív logikán alapuló, kvalitatív módszertanra épült. A kutatás eredményeként a szerzők megállapítják, hogy a Magyarországon működő energetikai nagyvállalatok stratégiájában explicit vagy implicit módon fókuszban van az innováció, de az innováció megvalósítása a hagyományos struktúrákkal, a szervezeti kultúrával, illetve a tudásmenedzsmenttel összefüggő külső és belső korlátozó tényezőkbe ütközik. A megújulási nehézség kezelésére az energetikai nagyvállalatok új szervezeteket hozhatnak létre, $s$ ezzel strukturálisan elkülöníthetik az új üzleti területek fejlesztését a hagyományos tevékenységtől, vagy irányított szervezeti változásokat hajthatnak végre, mellyel mérsékelt strukturális szeparációt és kontextuális fejlesztést alkalmazhatnak az innovációs képességek kiaknázását támogató feltételek kialakítása érdekében.

Kulcsszavak: innováció, innovációmenedzsment, szervezeti változás, változásvezetés, energetika

$\mathrm{Az}$ energiaszektor globális átalakuláson megy keresztül, melynek föbb trendjei a fenntarthatóságra való törekvés (Ergüden - Catlioglu, 2016), a megújuló energiák térnyerése (Bollino - Madlener, 2016), a decentralizált megoldások terjedése (Adil - Ko, 2016), az okoseszközök egyre szélesebb körben való használata (Alagoz - Kaygusuz, 2016) és az energiahatékonyságra és -biztonságra való fókuszálás (Costa-Campi et al., 2014).

A globálisan átalakuló energiaszektor által az energetikai nagyvállalatokra nehezedő megújulási kényszert az innovációmenedzsment és tudásmenedzsment perspektívájából elemezve a nemzetközi szakirodalomban olyan stratégiai ajánlásokat, illetve vezetői kihívásokat azonosíthatunk, mint (1) a kutatás-fejlesztés hosszú távú orientációját, (2) a szervezeti nyitottságot, a nyitott innovációt, (3) új üzleti területek fejlesztésére új szervezet alapítását és/vagy kiszervezést, (4) a vállalaton belüli vállalkozás és a szervezeti innovátorok támogatását, (5) a szervezeti tudás menedzselésének támogatását információtechnológiai lehetőségekkel és (6) stratégiai befektetéseket és felvásárlásokat (Zavarkó et al., 2017).

A szakirodalom alapján fontos felhívnunk a figyelmet arra, hogy a megújulást számos külső és belső tényező korlátozza a globális energiaszektorban: (1) szigorú külső szabályozás, mely főként a (korábban) nemzetállami szinten kritikus energiaellátási tevékenységből, illetve esetenként az állami tulajdonlásból fakadó (Nisar et al., 2016; Cullman et al., 2016), (2) nagy szervezeti méret és bürokrácia, mely az innovációhoz kapcsolódó döntések meghozatalát nehezíti (Costa-Campi et al., 2014), (3) a jelenlegi technológia és erőforrások dominanciája, melyek nehezítik az új technológiákra való fókuszálást (Anadon et al., 2011; OECD, 2011; Markard - Truffer, 2006; Salies, 2010).

Mivel az energetikai nagyvállalatok megújulását külső és belső tényezők nehezítik, ezért az innováció- és tudás- menedzsment-technikák önmagukban nem elégségesek a megújuláshoz: a külső és belső tényezők egyaránt akadályozzák az innovációs kapacitások kibontakoztatását, ezáltal veszélyeztetik a hosszú távú eredményességet, így szervezeti változásokra és változásvezetésre van szükség.

A nemzetközi szakirodalom és a felvázolt elméleti modellek alapján a szerzők a magyar energiaszektor nagyvállalati szegmensében vizsgálták a megújulási kihívásokat, illetve az innovációmenedzsment és a szervezeti változások, változásvezetés közötti összefüggéseket.

Jelen cikk célja a kutatás alapján azonosított innovációmenedzsmenttel kapcsolatos kihívások és az erre adott, illetve a szakirodalom alapján adható változásvezetési megoldások bemutatása.

A következőkben (1) először a stratégiát, az innováció és a szervezeti változás elméleti hátterét, illetve az iparági kontextust mutatjuk be, melyet (2) a módszertan, majd (3) a kutatási eredmények ismertetése követ, végül pedig (4) a következtetések, az innovációs célok megvalósítását szolgáló változásvezetési lehetőségek olvashatók.

\section{Elméleti háttér}

\section{A stratégia és az innováció kapcsolata}

A (nagy)vállalatok a hosszú távú eredményességet belső és külső kihívások leküzdésével érhetik el. Belső kihívás, hogy a szervezeti méret növekedésével megnő a koordináció és a szabályozottság iránti igény, mely által a szervezet tovább növekedhet, ugyanakkor a szervezet növekedési határának elérésekor megújulási krízissel szembesül, melyet a külső partnerekkel történő kollaboráció révén is csak ideiglenesen képes kezelni. Ennek oka, hogy a kívülről érkező impulzusok is kimerülnek, melynek eredményeként a szervezet (1) hanyatlani kezd, (2) stagnálni fog, vagy (3) visszatér az eredeti tevékenységéhez (Greiner, 1972; Balaton et al., 2009). 
A kontingenciaelmélet alapján (Lawrence - Lorsch, 1967; Pugh et al., 1969) a (nagy)vállalatoknak - a versenyképes müködés érdekében - alkalmazkodniuk kell a külső környezethez, következésképp a környezeti feltételek módosulása - a módosulás mértékének megfelelö - változást tesz szükségessé a szervezet lényeges jellemzőiben (Dobák, 2002; Antal - Dobák, 2004). A megújulás érdekében a stratégiát módosítani/átalakítani és azt végrehajtani szükséges. A nagyvállalat azonban stratégiai dilemma előtt áll, mivel a stratégiát úgy kell alakítania, hogy egyszerre legyen képes a jelenben, a rendelkezésre álló erőforrásokkal a lehető leghatékonyabban müködni (kiaknázás), s mindemellett a jövőre fókuszálva új lehetőségeket keresni és innoválni (felderítés), biztosítva a hosszú távú eredményes müködést (Duncan, 1976; March, 2012). Ez a kettős képesség dilemmája, mely természetesen érinti a piacokat, üzletágakat, a divíziók sorsát is. Ez a döntési helyzet Greiner modelljéből is kikövetkeztethető, hiszen ,az eredeti tevékenységhez való visszatérés" a stratégiai fókusz újbóli kijelölését jelenti, ami különböző üzletágak sorsáról való stratégiai döntést hozhat magával.

Az erőforrás-elosztás dilemmái egyes piacoknál érintik az innovációt is, hiszen azzal, hogy egyes üzletágak, piacok megszüntetése vagy fejlesztése mellett dönt a szervezet, egyúttal determinálja az innovációs irányokat és beruházásokat is. Schumpeter meghatározása óta (1938) az innováció lényegi eleme az újdonság, melyet Fejes (2015) még számos szakirodalmi meghatározást megvizsgálva a haladással, fejlődéssel egészít ki. Az innováció a kettős képesség mindkét területén értelmezhető: míg a diszruptív, piacteremtő (Christensen et al., 2015) és radikális (Hámori - Szabó, 2012) innovációk jellemzően a hosszú távú eredményesség miatt fontosak, addig az inkrementális, lépésről lépésre történő fejlesztések gyakran a rövid távú hatékonyságnövelést célozzák (Chikán, 2008; Hámori - Szabó, 2012). Ugyanakkor a felderítés és a kiaknázás között - föként a szükös erőforrásokból fakadóan - ellentét feszül, melynek feloldását a szakirodalom két irányból közelíti: (1) a strukturális szeparáció a rövid távú hatékonyságra és a hosszú távú eredményességre fókuszáló tevékenységek más-más szervezetben (szervezeti egységben) való megvalósítását jelenti, (2) míg a kontextuális fejlesztés során cél az adott szervezet (szervezeti egység) folyamatait, kultúráját, rendszereit olyan irányban módosítani, hogy az támogassa az ellentétes fókuszú feladatokat szimultán összehangoló magatartást (Taródy, 2012).

A hatékonyság - eredményesség és a stabilitás - változás dilemma megjelenik az innováció szintjén is, mert egyensúlyt kell teremteni a jelenlegi megoldások maximális kihasználása és az új megoldások kifejlesztése között (Sára et al., 2014).

Ezt az egyensúlyt az innovációs-növekedési stratégiák időbeli és adott vállalati kontextushoz illeszkedő alakításával lehet biztosítani: egyes időszakokban magas erőfeszítéseket kell tenniük a vállalatoknak, hogy innovációt valósítsanak meg és vezessenek be, de mivel az ilyen radikális innovációk jelentős változást generálnak a szervezetben, szükség van stabil, nyugodtabb időszakokra is, mely az innovációs képességek fejlesztését helyezi középpontba (Dobák - Hortoványi - Szabó, 2012).

Az előzőek, illetve Chikán (2008) alapján az innovációs stratégiák a vállalati stratégiából és a fogyasztói szükségletekből következnek, illetve az innováció (mint funkció) jövőorientáltsága révén a legszorosabban függ össze a vállalati stratégiával a részstratégiák közül. Ugyanakkor Fejes (2015) az innovációvezérelt stratégia mellett (melyben az innováció a vállalati stratégián alapul, azaz egy részstratégia), azonosítja az innovációalapú stratégiát is, melyben olyan mértékű az innovációs kényszer, hogy a vállalati stratégia alapul az innovációs célokon. Az eddigi megközelítések a vállalati stratégia és az innovációs stratégia viszonyára vonatkozóan implicit magukban hordozzák a porteri, külső, versenykörnyezet-fókuszú stratégiaelmélet előfeltevéseit, de az innováció mint a megújulás kulcseleme domináns az erőforrás-alapú megközelítésekben is: a dinamikus képességek elméletében (Teece, 2011) a vállalati és az innovációs stratégia összefonódik, hiszen a folyamatos megújulás jegyében kell az új üzleti lehetőségeket időről időre felismerni, az erőforrásokat mozgósítani és alakítani az értékteremtő folyamatokat (Fejes, 2015). Az erőforrások mozgósítása és az értékteremtő folyamatok átalakítása szintén magában hordozza az üzleti lehetőség (másképpen: innovációs cél) kihasználása érdekében végrehajtandó szervezeti változásokat.

\section{Az innovációmenedzsment és a szervezeti változás}

A nagyvállalat tehát a környezet változásai és a nagy szervezeti méretből fakadó szabályozottság miatt megújulási krízisben van. Mivel az innováció lényege a haladás, a fejlődés, az újdonság és a fogyasztóorientáltság, az innováció a megújulás szinonimájaként is értelmezhető; mindemellett új termékek/szolgáltatások, új technológia és/ vagy új szervezeti megoldások bevezetése révén a vállalat képes javítani, biztosítani versenyképességét, illetve követni, vagy akár befolyásolni a külső környezeti trendeket (Hortoványi - Balaton, 2016; Chikán, 2008; Fejes, 2015). E megújulási folyamat első lépése az innovációhoz kapcsolódó stratégiai döntések meghozatala, melyet az előzőekben bemutatott kettős képesség dilemmája nehezít.

A stratégiai döntéshozást követően az innovációt (is) menedzselni, vezetni szükséges: Antal és Dobák (2004) alapvető vezetési funkciói és a szakirodalmi innovációdefiníciók (Fejes, 2015) alapján (1) az innovációs irányok kijelölése után (tervezés) (2) az innovációs folyamatok kialakítása, a rendelkezésre álló erőforrások, képességek újszerü kombinálása és a hiányzó erőforrások, képességek megszerzése (szervezés), (3) az innovációt támogató szervezeti kultúra kialakítása (személyes vezetés), illetve (4) az innovációs képességek és eredmények ellenőrzése (kontroll) a vezetői feladat (Zavarkó et al., 2017). E tervezési, megvalósítási és ellenőrzési tevékenységek összekapcsolódnak, s a rendszerben való értelmezésben fontos szerepet kap a visszacsatolás és a vezetői beavatkozás is szükség esetén (Bodnár - Dobák - Lázár, 1997).

A visszacsatolás és beavatkozás az innováció implementációjában is rendkívül releváns tevékenység, mivel 
azt több szervezeti tényező is hátráltatja. Ezek közös gyökere, hogy a megújulási folyamat elindulása a szervezetben megszünteti a stabilitást és változást generál (Csedő, 2006; More, 2011; Fejes, 2015), a változás pedig szervezet több lényeges jellemzőjének megváltozását is jelentheti: a stratégiai döntések például strukturális vagy akár kulturális átalakításokkal járhatnak (Dobák, 2002).

Ebben a kontextusban tehát irányított változásról beszélünk, melynek célja a szervezeti teljesítmény növelése vagy fenntartása (Bakacsi, 2004; Dobák, 2002). A szakirodalom a változás típusait sokféleképpen tárgyalja: Csath (2001) tipizálása a változás rendszerhez való viszonyával kapcsolatos (morfostatikus: a rendszeren belüli változás, morfogenetikus: a rendszer maga változik), Dobák (2002) némileg más közelítésből a változás intenzitását, mértékét vette alapul (inkrementális, radikális), míg a vezetői célkitűzés alapján Beer és Nohria (2001) két típust határoz meg:

a. az E-típusú változás során a cél a gazdasági érték maximalizálása, mely egy felülről irányított, struktúrát és folyamatokat érintő, tudatosan vezérelt, ösztönzési rendszerrel kombinált változási folyamatot jelent,

b. az O-típusú változás során a szervezeti képességek fejlesztése kerül a fókuszba, mely inkább alulról fejlődő, kultúraorientált, a vezetés korlátozott mértékü részvételével valósul meg (Beer - Nohria, 2001).

A szakirodalmi adatok alapján kijelenthetjük, hogy az innováció és a szervezeti változás között lehetnek összefüggések. A szervezeti változás azért szükséges, mert ahogyan a stratégiának illeszkednie kell a külső környezethez és a belső adottságokhoz, úgy az innovációs stratégiának is illeszkednie kell a belső adottságokhoz. Mivel megközelítésünkben a külső környezet (és a vállalati stratégia) determinálja az innovációs célokat, a belső adottságokat kell módosítani, fejleszteni. Ez szervezeti változások és változásvezetés szükségességét jelenti. Az innovációs tevékenységek számára a szervezeti változások által teremtett kedvező belső környezet akár olyan diszruptív innovációkat eredményezhet, mely visszahat a külső környezetre.

Továbbá a változásvezetés azért is kritikus, mert a megújulással együtt járó változással szemben (mely jelentős strukturális, vagy akár kulturális átalakításokat, illetve új magatartásminták elsajátítását jelentheti) az alkalmazottak idegenkednek, ellenállnak. A szervezeti ellenállás miatt az új magatartásminták elsajátítása és követése elmarad. Sull (1999) azt a jelenséget, amikor a szervezet a drasztikus környezeti változások ellenére is a meglévő mintákat követi, aktív tehetetlenségnek hívja. Ez egy komoly versenyképességi (megújulási) probléma, hiszen - a kontingenciaelmélet alapján - hiába illeszkedik a formális stratégia és a struktúra a környezethez, ha a kultúra illeszkedése nem megfelelö, a teljesítmény alacsony lesz (Antal - Dobák, 2004). Másképpen: hiába helyesek az innovációhoz kapcsolódó döntések, ha az innováció implementációja korlátozott mértékü, a megújulási krízis fennmarad, és a szervezet hanyatlani kezd (Hortoványi Szabó, 2008).
Összefoglalva, az innovációs célok eléréséhez olykor lényeges szervezeti jellemzők megváltoztatására van szükség, és a változtatással együtt járó szervezeti ellenállást is kezelni kell. Mindebből az következhet, hogy a változásvezetés a nagyvállalati innováció implementációjának elengedhetetlen eszköze. Másik megközelítésben nemcsak az innováció megvalósítása, de annak megvalósulása is generálhat változást a szervezetben (pl.: egy új gyártási technológia miatt átalakulnak a folyamatok), melynek elfogadását szintén támogatni szükséges.

\section{Iparági és történeti háttér}

Az energiaszektor világszerte jelentős átalakuláson megy keresztül, Schaeffer (2015) a változás hajtóerői közé általános makrokörnyezeti tényezőket (például globális gazdasági válságok, geopolitikai feszültségek, klímaváltozás), illetve iparági jelenségeket sorol (például a fejlődő országok növekvő energiaszükséglete, az Egyesült Államok palaolaj és palagáz kitermelésének hirtelen növekedése, az atomenergia háttérbe szorulása, az olaj piaci árának és jelentőségének folyamatos változása, a megújulóenergia-technológiák drasztikusan csökkenő költsége). E változások, illetve a bevezetésben említett iparági trendek megújulási kényszert jelentenek, melyekhez speciális iparági menedzsmentkihívások is kapcsolódnak:

1. A fenntarthatóság összeegyeztetése a kettős értékteremtéssel: Høgevold és Svensson (2012) hangsúlyozzák, hogy a vállalati fenntarthatósági törekvés nem a növekedés és a profitmaximalizálás alternatívája, inkább kiegészítő cél. A fenntarthatósági szemlélet esetében Hernádi (2012) az erőforrások és az üzleti tevékenységek felülvizsgálatának szükségességére mutat rá.

2. A politikai szabályozásnak való megfelelés: A fenntarthatósági kezdeményezések, egyezmények és irányelvek az energetikai vállalatok piaci és fejlesztési tevékenységeinek alakítása szempontjából meghatározóak: Az EU megújulóenergia-stratégiájának célja 2020-ra elérni a megújulók 20\%-os arányát (Parobek et al., 2016). Emellett a politikai téren nemcsak a célokat, hanem a célelérés eszközeit is meghatározták: Ruiz-Abellón és társai (2016) rámutatnak, hogy az EU a villamosenergia-piac integrálására törekszik, mely révén a megújuló erőforrások nagyobb volumenben és jobb allokálással hasznosíthatók az energiamixben.

3. Az infrastruktúrával kapcsolatos kihívások: Az energetikai vállalatoknak az iparági változás kihívást jelent egyrészt a fizikai infrastruktúra vonatkozásában, mivel a decentralizált megoldások nem teljes mértékben kompatibilisek a meglévő fizikai rendszerekkel, illetve üzleti téren is, mivel új típusú üzleti, tulajdonlási és müködtetési modellekre van szükség: például (1) fogyasztói rendszerek, (2) kisebb közösségi rendszerek, (3) vegyes rendszerek az energetikai cégek közremüködésével, vagy (4) önkormányzati rendszerek kialakítására (Adil - Ko, 
2016). Luthra és társai (2014) rámutatnak, hogy a növekvő energiaszükségletet és az energiahatékonyság iránti igényt a hálózatok müködtetésének optimalizálásával elégíthetik ki az energetikai vállalatok, mindehhez pedig az okoseszközök használatára van szükség. Schaeffer (2015) ezzel kapcsolatban pedig arra világít rá, hogy a szükséges és terjedő új ICT-megoldások új kontrollrendszereket és stratégiákat is igényelhetnek.

E kihívásoknak való megfelelést az általános menedzsmentkihívásokon túl az energiaszektor speciális történeti helyzetéből fakadó sajátosságok is nehezítik. Nisar és társai (2016) a napjainkban gyakran alkalmazott nyitott innovációs szemléletet támogató szervezeti struktúra megvalósulását vizsgálták energetikai cégek esetében. A szerzők rámutatnak arra, hogy a szervezeti nyitottság (és ezáltal az innovációs képesség) nemcsak a belső szervezeti tényezőktől függ. Az energiaszektort a legtöbb fejlett országban részletes és szigorú szabályozás, merev intézményi keretrendszer jellemzi, s a külső környezet szervezeti lecsapódása a nyitottságot, együttműködést, innovációt kevésbé támogató struktúrákat eredményez (Nisar et al., 2016). A szerzők arra is utalnak, hogy a rugalmatlan szabályozási és szervezeti környezet abból fakad, hogy történelmileg az energia közjónak minősül, illetve az energiaellátás kontrollálása és biztosítása nemzetállami szinten kritikus tevékenységnek számít(ott). Ebből a jelenségből következett a korábban domináns állami szerepvállalás és tulajdonlás az energiaszektorban, melyet az 1990-es években jelentős privatizációs hullám, majd napjainkban az állami tulajdon részesedésének újbóli növekedése követett (Cullmann et al., 2016).

A szakirodalom alapján a szigorú külső szabályozás mellett belső rugalmatlanság is jellemzi az energetikai nagyvállalatokat. Costa-Campi és társai (2014) Cohen (2010) empirikus kutatásai alapján megállapították, hogy a vállalat nagy mérete a kutatás-fejlesztés hátráltató tényezője lehet, elsősorban a beruházás indokoltságát és célját, tárgyát érintő kérdésekben való döntés hosszadalmassága, nehézségei miatt, ráadásul ez a jelenség az energiaszektorban még relevánsabb, mivel jellemzően az iparág erősen koncentrált (Costa-Campi et al., 2014).

Végül a kutatások alapján a hagyományos technológiák és erőforrások használata is a megújulást nehezíti. Anadon és társai (2011) és az OECD (2011) kutatásai egyaránt arra jutottak, hogy a meglévő, hagyományos technológiák dominanciája akadályozza az innovációs folyamat megkezdését új területeken, de negatív hatással van az innovációs tevékenységekhez kapcsolódó eredményelvárások konszenzusának létrejöttére is. Markard és Truffer (2006), illetve Salies (2010) a fosszilis és nukleáris energiatechnológiák létét és használatát a megújuló energiákkal kapcsolatos radikális innovációk korlátjának minősítik. A vállalati méret, a piaci koncentráció és a meglévő technológiák dominanciája egyaránt a szervezeti tehetetlenséget és az útfüggőséget erősítik.

A bemutatott megújulást korlátozó iparági (és történeti) tényezők a magyar energiaszektorban is relevánsak le- hetnek, mivel (1) jelentős az állami tulajdon az iparágban (pl.: MAVIR, MVM-csoport, Nemzeti Közmüvek), (2) a 2007. évi LXXXVI. törvény és a 2008. évi XL. törvény a földgázellátásról pontosan rögzíti és szabályozza az engedélyköteles tevékenységeket, továbbá (3) a piaci koncentrációt vizsgálva elmondható, hogy mind a villamosenergia-, mind a földgázpiacon egy-egy vállalatcsoport az ellátási lánc több tevékenységének (például termelés, elosztás, kereskedés, egyetemes szolgáltatás) végzéséhez rendelkezik engedéllyel (például MVM-csoport, E.ON, ELMÜ-ÉMÁSZ (RWE tulajdonú vállalat), NKM). Összegezve, a nemzetközi trendek mellett a megújulást korlátozó szakirodalmi tényezők a magyar energiaszektorban is irányadóak a kutatáshoz.

\section{Kutatási kérdések és módszertan}

A kutatás a magyar energiaszektor nagyvállalatainak innovációs kihívásaira és az ezekhez kapcsolódó szervezeti változásokra fókuszált. A kutatás célja kvalitatív módszertannal feltárni (1) az innováció vállalati kontextusát és a vállalati stratégiában való megjelenését, (2) az innováció gyakorlati implementációjának nagyvállalati kihívásait (3) és e kihívásokhoz kapcsolódó szervezeti változásokat és változásvezetési stratégiákat a Magyarországon müködő energetikai nagyvállalatok esetében.

A kutatás fókusza a magyar energiaszektor nagyvállalati szegmense, melybe olyan vállalatokat/vállalatcsoportokat soroltunk, melyek jelen vannak a villamosenergia-piacon és/vagy a földgázpiacon, továbbá széles körü energetikai termék- és szolgáltatásportfólióval rendelkeznek, Magyarországon 250 fónél több embert foglalkoztatnak, illetve akár az ellátási lánc több tevékenységében is részt vesznek: rendszerirányítás/üzemeltetés, termelés, elosztás, kereskedés, egyetemes szolgáltatás. A hazai energiapiacon - az elmúlt időszak iparági változásaival összhangban (pl.: új belépők, felvásárlások, kivonulások) - több vállalat (vállalatcsoport) is megfelel a fenti feltételeknek, például: MOL-csoport, FÖGÁZ, NKM Nemzeti Közművek (korábbi nevén: ENKSZ), MVM-csoport, E.ON, ELMÜ-ÉMÁSZ (utóbbi a német multinacionális energetikai cég, az RWE többségi tulajdonában áll), vagy EDF (a kutatás idején még a DÉMÁSZ tulajdonosa). E szervezetek ugyanakkor számos szempontból nem tekinthetők homogénnek (pl.: szervezeti és irányítási rendszerek), ám a felsorolt egyezőségek révén az iparági szintű, betekintés jellegű kutatás fókuszcsoportját képezik.

A kutatás során kvalitatív módszertant alkalmaztunk: olyan vezetőkkel készültek félig strukturált interjúk, akik (1) energetikai nagyvállalatokban dolgoznak vagy dolgoztak, így képviselve a belső nézőpontot, illetve, akik (2) energetikai nagyvállalatokkal szerződéses kapcsolatban álló vállalatokban betöltött vezető szerepük miatt, külső szemlélőként beszéltek tapasztalataikról, meglátásaikról. A kutatás során 15 interjú készült energetikai innováció menedzselésében jártas szakemberekkel, akik az előző bekezdésben felsorolt szervezetek közül eggyel vagy többel vannak, vagy voltak munkakapcsolatban, s akik mindegyike szigorú anonimitás mellett vállalta az interjúban 
való részvételt. Az interjúk megállapításai nem kapcsolhatók kizárólagosan egy adott vállalat jellemzőivel össze, a beszélgetések során rendszerint iparági szegmens szintü megállapítások hangzottak el, több vállalat sajátosságait említve, összegezve.

A félig strukturált interjúk öt téma köré rendeződtek: (1) általános vélekedés az energetikai nagyvállalatok stratégiájáról és megújulási képességeikről, (2) benyomások az iparágról, a külső környezeti változásokról, (3) az innováció interpretálása, vállalati innovációs képességek elemzése, (4) a stratégia és az innováció kapcsolata, (5) az innováció megvalósítása, implementációs stratégiák, kihívások, korlátok.

A vállalati kontextus alapos megismeréséhez dokumentumelemzést is alkalmaztunk, mely során vállalati stratégiákat, akcióterveket, innovációs projekteket elemeztünk a rendelkezésünkre bocsátott vállalati dokumentumok alapján. Az innováció jelentésének, jelentőségének és megvalósítási kihívásainak stratégiai kontextusban való elemzésekor az összvállalati (vállalatcsoport szintü) stratégia jelentette az értelmezési keretrendszert.

A vizsgált jelenség, azaz a megújulási kényszerre való reagálás, az innovációmenedzsment és a szervezeti változás az energetikai nagyvállalatokban egy napjainkban zajló és a versenyképességet alapjaiban érintő jelenség, emiatt is indokolt a kvalitatív módszertan alkalmazása (Yin, 2003), az interjúalanyok szigorú anonimitása és a kutatás általános jellegü közelítése.

Összességében a kutatás iparági szegmens szinten és ebből következően egy tágabb stratégiai értelmezési keretrendszerben valósult meg, a megismerés egy átfogóbb formáját és diskurzusra ösztönző elméleti modell megalkotását célozva.

\section{Kutatási eredmények}

A kutatás kiindulópontja az energetikai nagyvállalatok formális stratégiájának elemzése volt. A dokumentumelemzés alapján egyértelműen körvonalazódik sok közös pont: domináns a technológiai innováció, a fogyasztóorientált megoldások kifejlesztése és a fenntarthatóságra való törekvés. Minden Magyarországon (is) müködő energetikai nagyvállalat esetében explicit vagy implicit (fejlesztés, fejlődés, újítás) módon fókuszban van az innováció.

\section{Az innováció vállalati stratégiában való megjelenése és jelentéstartalma}

Az interjúk alapján az innováció leginkább új technológiákra épülő új üzleti modellek kifejlesztését és bevezetését jelenti az energetikai nagyvállalatokban, azaz a technológiai fejlesztés és az üzletfejlesztés kapcsolatára épül. Ugyanakkor mélyebb szinteken az alkalmazotti és középvezetői körben az innovációhoz gyakran negatív attitűdök kapcsolódnak, mivel az innovációközpontú, megújulási stratégia nehezen „fér össze” az elzárkózó szervezeti kultúrával. A mérnöki, erőmüvi kultúra zárt gondolkodási struktúrája és a kockázatkerülés ellentéte az innovációval járó bizonytalanságnak, az innovációhoz szükséges nyi- tott gondolkodásnak. A nyitott gondolkodás során nem problémák, hanem lehetőségek vannak a fókuszban, azonban a hagyományos energetikai rendszerekhez szokott munkavállalói körben ,a megújuló technológiákra problémaként tekintenek". A külső környezet gyors változásai által generált megújulási kényszer és a felső vezetés által kihirdetett innovációközpontú stratégia a mérnöki, erőmüvi szervezeti kultúrával nehezen integrálható: feszültséget, sőt nemcsak egyéni, de ,csoportszintű kognitív disszonanciát”, ,irritációt” eredményez.

Az innovációval és megújulással szemben további negatív attitüdöt jelent, hogy a vertikálisan integrált (közös tulajdonossal rendelkező, az ellátási lánc több tevékenységében résztvevő) vállalatcsoportok hagyományos üzletágakban tevékenykedő leányvállalatai egyáltalán nem érdekeltek az „új technológiákra épülő új üzleti modellek” kifejlesztésében és megvalósításában.

Az innováció jelentéstartalmát és stratégiai jelentőségét Fejes (2015) terminológiájával összevetve az állapítható meg az interjúk alapján, hogy a villamosenergia-piacon tevékenykedő vállalatok esetében nagyobb a megújulási kényszer, így náluk azonosítható inkább az innovációalapú stratégia, semmint a kizárólag földgázpiaci szereplőknél.

\section{Az innováció megvalósításának kihívásai}

A stratégia által definiált innovációs törekvések megvalósítása számos, többnyire már az előzőekben is említett kihívásba, korlátba ütközik. Az innováció megvalósításának folyamatát és annak korlátozó tényezőit a következőkben néhány fontos környezeti és szervezeti jellemzö szerint rendszerezve mutatjuk be.

\section{Külső környezet és tudás}

A vezetők egyetértettek abban, hogy a szigorú szabályozási háttér korlátozza az innovatív üzleti modellek implementálását (pl.: engedélyköteles tevékenységek köre), az árszabályozás és a piacok liberalizációja miatt beáramló külföldi olcsó energia pedig rontja a jövedelmezőségi kilátásokat, mely az innovációs projektekre fordítható öszszegek mértékére is negatív hatással van. Emellett az is problémát jelent az innovációs célok elérésében, hogy bár a külső tudás becsatornázása révén a megújulási folyamat új lendületet kaphat, Magyarországon

a. a nagyvállalatokon kívül számos piaci szegmensben hiányos az új technológián alapuló új üzleti területek felderítéséhez és kiaknázásához az energetikai szakkompetencia (az új energetikai, tanácsadási szolgáltatások esetében ugyanakkor ez akár piaci lehetőséget, felvevőpiacot is jelenthet),

b. az innovatív energetikai vállalkozók gyakran nincsenek tisztában a jogszabályi lehetőségekkel és korlátokkal,

c. kevés a „valódi, piaci problémára, vagy tényleges vevői igényre megoldást nyújtó innovatív ötlet",

d. szélesebb társadalmi aspektusban vizsgálva is alacsony a vállalkozó kedv és kezdetleges az innovációs kultúra. 


\section{Tulajdonosi szerkezet}

Több interjúalany is kifejezte azt a benyomását, hogy az állami tulajdonú vállalatokban alacsonyabb a kockázatvállalási hajlandóság, mivel e vállalatok vezetői teljesítményértékelő rendszere a rövid távra való optimalizálást támogatja. Amíg a rövid távon megszerezhető profit a legdominánsabb teljesítményértékelő szempont, addig a kockázatvállalás, a hosszú távú eredményességet támogató innovációs beruházások (akár diszruptív technológiákba való befektetések) motivációs korlátokba ütköznek.

Ebből következik az az ellentét, hogy míg az innováció stratégiai szinten hangsúlyos, a megvalósítás kockázatkerülő vezetői döntésekkel párosul, illetve maga az innovációs célok megvalósítása nem folyamatos, inkább „stop-go” ciklusokra épül. Szintén ide kapcsolódnak az állami vállalatok stratégiájában domináns ellátásbiztonsághoz tartozó és társadalompolitikai célok, melyek a gyakorlatban olykor hangsúlyosabbak, mint a megújulási törekvések.

\section{Struktúra és folyamatok}

Kutatási eredményeink alapján egyértelműen megállapíthatjuk, hogy a nagyfokú hierarchizáltság és szabályozottság is gátolja az innovációt, mert kódolja a rugalmatlanságot. Az interjúalanyok arra is rámutattak, hogy ez egy általános nagyvállalati jelenség: ,egy nagyvállalat dinamikája nem támogatja az innovációt”, ,,az innováció jellegét, lényegét elnyomják a nagyvállalatban”. Ez különösen megmutatkozik a döntések hosszú átfutási idejében, mely a környezeti változásokhoz való lassú alkalmazkodást eredményez.

Az interjúalanyok tapasztalatai alapján az innováció gyakorlati implementálása strukturálisan eltérő a nagyvállalatokban az alábbiak szerint:

a. a bimodális működés során teljesen szétválasztják az innovatív törekvéseket és a hagyományos működést,

b. a mátrixmüködésben az innováció egy második tengelyként jelenik meg a funkcionális/divizionális tengely mellett, így lehetőség nyílik a horizontális együttmüködések létrehozására (nem jellemző az energetikai nagyvállalatoknál),

c. egy dedikált szervezet jogilag is elhatárolódik, az anyaszervezetből kiszakadva eltérő müködési logikák mentén végzi az innovációs tevékenységet,

d. decentralizált innovációmenedzsment során a tagvállalatok/divíziók önmaguk koordinálják az innovációs tevékenységeket.

\section{Szervezeti kultúra}

Az előzőekben részletesen kifejtett mérnöki kultúra, a zárt gondolkodás, a kockázatkerülés, a berögzült szokások és az újdonságokkal (pl.: megújulók) szembeni negatív attitüd korlátozza az innováció bottom-up kibontakozását.

A hierarchizált szervezetben és a szigorú szabályozás mellett az évtizedek során az energetikai nagyvállalatok alkalmazotti és vezetői szerepei az innovációt korlátozóan rögzültek. Az innovációhoz kockázatvállalás, felelősségvállalás, nyitott gondolkodás, nyílt kommunikáció, kollaboráció, kreativitás, a konfliktusok felvállalása lenne szükséges (Bakacsi, 2004), azaz dominánsan „felnőtt” szerepet, magatartást igényel. A szabad „gyerek” szerep csak az ötletgenerálásnál, míg a kontrolláló „,szülő” szerep a visszamérésnél lenne adekvát.

Ehhez képest a hagyományos energetikai nagyvállalatok rendkívül hierarchikus rendszerében az alábbi magatartásminták érvényesülnek:

1. a szakértők és a középvezetők gyakran engedelmeskedő „gyerek” szerepben vannak, azaz nem vállalnak felelősséget, nem vállalják fel a konfliktust, zártan gondolkodnak, nem osztják meg egymással a tudást és nagyon szabálykövetőek, míg mikor egyegy innovációs projekt esetében lehetőségük van kifejteni véleményüket, akkor olykor túlkompenzálnak és ,lázadó tinédzserként” viselkednek, gyakran destruktív magatartást mutatnak,

2. a vezetők úgy akarnak innovációt, hogy közben ragaszkodnak kontrolláló „,szülői” szerepükhöz, pedig a hagyományos vezetői szokásaik (tervezés, döntés, kontroll) nem alkalmasak az innovációs folyamat támogatására (pl.: nem támogatja a kísérletezést, „szükségtelen korai visszajelzést ad”). Másképp fogalmazva, az új helyzet új vezetői magatartásmintákat is igényelne.

A fentieken túl az egymással azonos horizontális szinteken lévő munkatársak is kevésbé képesek és/vagy hajlandóak a kooperációra, egyfajta tudásféltés és néha destruktív hozzáállás érzékelhető az innovációs projektekben.

\section{Innovációs projektek tapasztalatai}

Az „új technológiára épülő üzleti modellek” kifejlesztése az eddig megszokott, hagyományos tevékenységhez más tervezési és megvalósítási módszertant igényelne. Míg a hagyományos müködésben egy „újítás” elökészítése (pl.: új erőmü létesítése) több éves, akár tíz éves időhorizonton történt vízesés modellben valósul meg, addig a megújulásra, eredményességre fókuszáló termék- és szolgáltatásfejlesztés vagy digitalizáció, információtechnológia tárgyú innovációs projektben inkább az agilis fejlesztés lenne szükséges, folyamatos kísérletezéssel és tanulással. Ennek megvalósításához azonban gyakran hiányzik a szakértői kompetencia. A kompetenciahiány párosul azzal a módszertani hiányossággal is, hogy az innovációs projektötletek értékélésére nincsenek bevált metódusok (és a nagyfokú bizonytalanság miatt nem is lehetnek) és tapasztalatok sem. Az általános kockázatkerülés, a hiányos kompetencia és tapasztalat következménye a radikálisan innovatív projektek alacsony támogatottsága.

A vállalati innovációs stratégia megvalósítása a felsorolt külső és belső korlátozó tényezők miatt akadályokba ütközik, más megközelítésben az (innovációs) stratégia és a célok (1) meglévő struktúrákkal és rendszerekkel, (2) szervezeti kultúrával és (3) tudással kapcsolatos öszsze nem illése jelent nehézséget az innováció megvalósítása során. E tényezőket a külső-belső szempont szerint is rendszerezi az 1 . táblázat. 
1. táblázat

Innovációmenedzsment-kihívások az energetikai nagyvállalatoknál (saját készítés)

\begin{tabular}{|c|c|c|}
\hline & Külsó tényezők & Belső tényezók \\
\hline 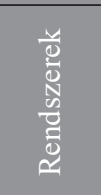 & $\begin{array}{l}\text { Merev szabályozási } \\
\text { környezet }\end{array}$ & $\begin{array}{l}\text { Erős hierarchia } \\
\text { Túlkontrolláltság } \\
\text { „Kódolt rugalmatlanság” } \\
\text { Rövidtávra fókuszáló telje- } \\
\text { sítményértékelő rendszer }\end{array}$ \\
\hline 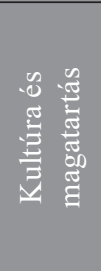 & $\begin{array}{l}\text { Alacsony vállalkozó } \\
\text { kedv és kezdetleges } \\
\text { innovációs kultúra a } \\
\text { társadalomban }\end{array}$ & $\begin{array}{l}\text { Mérnöki, erőmüvi szerveze- } \\
\text { ti kultúra } \\
\text { Kockázatkerülés, zárt gon- } \\
\text { dolkodás } \\
\text { Gyenge kooperáció } \\
\text { Inadekvát vezetői és alkal- } \\
\text { mazotti magatartásminták }\end{array}$ \\
\hline 苞 & $\begin{array}{l}\text { Kis mennyiségű a kí- } \\
\text { vülröl becsatornázha- } \\
\text { tó értékes energetikai } \\
\text { tudás, hiányos isme- } \\
\text { retek a szabályozási } \\
\text { környezetről } \\
\text { Kevés valóban in- } \\
\text { novatív ötlet érkezik } \\
\text { kívülről }\end{array}$ & $\begin{array}{l}\text { Hiányos vezetői kompe- } \\
\text { tenciák az új típusú, kísér- } \\
\text { letezést támogató, agilis } \\
\text { innovációs projektben } \\
\text { Kevés tapasztalat az inno- } \\
\text { vációs ötletértékelésben }\end{array}$ \\
\hline
\end{tabular}

\section{Az innovációs stratégiák hatékony nagyvállalati implementálására vonatkozó javaslatok}

Az innovációs célok megvalósítását számos belső tényező korlátozza az energetikai nagyvállalatok esetében, kutatási eredményeink alapján megállapíthatjuk, hogy az innovációs célok eléréséhez szervezeti változás is szükséges:

a. az energetikai szektor számos állami tulajdonú vállalatainál az állami vagyon kezeléséhez nagyobb felelösséget, nagyobb kockázatkerülést és rövid távú teljesítményértékelést észleltek, tapasztaltak az interjúalanyok, ezek pedig nem támogatják az innovációt; javaslatként az interjúalanyok azt hangsúlyozták, hogy nem célszerủ a magas kockázattal járó diszruptív innovációk felkutatására, fejlesztésére állami tőkét elkülöníteni, ha ahhoz rövid távra optimalizáló ösztönzők tartoznak,

b. az interjúalanyok szerint az új üzleti területek, stratégiai jellegű innovációk kifejlesztését, megvalósítását érdemes minél inkább strukturálisan és/vagy jogilag elválasztani a hagyományos üzleti modell megvalósításától,

c. az innovációs célok eléréséhez jelentős kultúrafejlesztést/kultúraváltást tartanak szükségesnek, mivel a jelenlegi mérnöki, erőművi, elzárkózó kultúra ellentétes az innováció jellegével,

d. az üzleti területeket érintő, nagy bizonytalansággal járó innovációs projektek a megszokottól eltérő alkalmazotti, illetve vezetői szerepeket és kompetenciákat igényelnek, melyeket sok képzéssel szükséges lenne támogatni.

\section{Következtetések}

\section{A szervezeti változás mozgatórugói: új ösztönzők, új struktúra, új kultúra}

Kutatási eredményeink szerint az innováció hatékony implementációjának egyik fontos tényezője az állami tőkéhez kapcsolódó felelősség és a rövid távra optimalizáló ösztönzők innovációs folyamatokban való inadekvát léte volt. Következésképp nem az állami innovációs tőkével magával, hanem az azzal gazdálkodók teljesítményértékelési rendszerével van probléma. A hosszú távú eredményességet támogató innovációs projektek sikeres megvalósításához a hagyományos ösztönzö rendszereken is változtatni kell. Az energetikára vonatkoztatva ez azt jelenti, ha a cél az átalakuló energiaiparhoz való alkalmazkodás, mely a hosszú távú eredményességet jelenti, a rövid távon való profitmaximalizálás az innovációval foglalkozó üzleti egységben, de akár összvállalati szinten sem lehet (kizárólagos) prioritás (kettős képesség dilemmája), hiszen a megújulást lehetővé tévö (gyakran radikális jellegü) innovációs projektek a jelenben csak költségeket jelentenek, és csak a jövőben termelnek árbevételt.

Az új üzleti területeket érdemes élesen elválasztani a hagyományos üzleti modellek müködtetésétől. Ez a kettős képesség megvalósításának kétféle módszertana közül (Taródy, 2012) a strukturális szeparációra utal, mely a bemutatott belső, hagyományos tevékenységből és nagyvállalati jellegből fakadó nehézségek (merev kultúra, struktúra, zárt gondolkodás) miatt megfelelőbb (de mindenképp gyorsabb) megoldásnak tünik, mint a kontextuális fejlesztés.

A szervezeti változás harmadik mozgatórugója a kultúrafejlesztés/kultúraváltás. Alapvető választás előtt áll számos energetikai nagyvállalat:

a. a hagyományos tevékenységtöl az új üzleti területeket teljesen elhatárolva kezelheti, különálló jogi entitást, kultúrát, struktúrát, teljesítményértékelő rendszert, vezetést létrehozva, ez a strukturális szeparáció megoldása, ez esetben a kultúrafejlesztés/kultúraváltás csak az új üzleti területekre fókuszál,

b. a vállalaton belül is elkezdődhet az innovációs folyamatok azonosítása és fejlesztése, bár kutatásaink alapján elég egyértelmủen körvonalazódik, hogy a jelenlegi szervezeti struktúra, folyamatszabályozás, kultúra nem támogatja az innovációt. Ez esetben is lehet strukturális szeparációt alkalmazni, de csak kevésbé radikálisan, inkább a kontextuális fejlesztésen van a hangsúly.

A fenti kihívásokhoz új típusú vezetői és szakértői készségek illeszkednek, melyekhez elengedhetetlen a jelenlegi szakértői/vezetői kör képzése, de szükségessé teszi az új készségeket, szakmai és módszertani ismereteket más iparágakban már elsajátított és kipróbált szakértők és vezetők bevonzása is. 


\section{Szervezeti változások az energetikai nagyvállalatoknál}

A hagyományos energetikai nagyvállalatok megújulását, az innováció megvalósítását az előzőekben részletesen bemutatott számos tényező korlátozza. A sikeres megújuláshoz, a hosszú távú eredményességhez szervezeti változásokra és változásvezetésre van szükség.

Az energetikai nagyvállalatok az innovációs célok kijelölése, az innovációs stratégia megalkotása után elsősorban strukturális döntések előtt állnak: (1) új szervezetet hoznak létre vagy (2) szervezeten belül koordinálják az innovációt. Előbbi esetében szervezettervezési feladatok, utóbbi esetében strukturális és kulturális átalakítás, illetve humánerőforrás-fejlesztés szükséges az innováció sikeres megvalósításához. Mindkét esetben a változás célja, hogy kedvező feltételeket (rendszereket, kontextust) teremtsenek az innovációhoz, melynek fó pillérei:

a. rugalmas, hálózatos együttmüködést támogató struktúra,

b. nemcsak a mérnöki kultúrából érkező vezetői csapat,

c. a vállalkozást, kísérletezést, kockázatvállalást és felelősségvállalást támogató szervezeti kultúra és vezetői példamutatás,

d. hosszú távú eredményességre ösztönző teljesítményértékelö-rendszer.

A kutatási eredményeink alapján kijelenthetjük, hogy nehezen képzelhető el az innovációs célok hatékony implementálása egy E-típusú változásvezetés nélkül, mely látványosan átrendezi a hagyományos szervezeti struktúrát, rendszereket az innováció számára sokkal kedvezőbb rendszerszintủ feltételeket teremtve. Ezt követheti majd egy O-típusú változás megvalósítása a fokozatos kulturális hozzáillesztés érdekében, alulról építkező innovációs kultúrafejlesztő projektek támogatásával.

\section{Az innováció által indukált szervezeti változások modellje}

$\mathrm{Az}$ energiaszektor nagyvállalatainak esetében a vállalati stratégiából következő innovációs célok megvalósítása olykor külső és belső akadályokba, vállalati struktúrákkal, rendszerekkel, kultúrával, illetve tudás- és tapasztalathiánnyal kapcsolatos akadályokba ütközik. Az (innovációs) stratégia és a többi lényeges szervezeti tényező közötti illeszkedés elősegítésére új szervezetet, új struktúrákat, új rendszereket hozhatunk létre, melyek kritikus jellemzőit az innovációs célok mentén kell megtervezni, kialakítani, azaz célszerü minél inkább elválasztani a müködést a hagyományos üzleti modellben müködő anyavállalatétól (strukturális szeparáció). Az alternatív lehetőség a jelenlegi szervezeten belüli megvalósítás, ez esetben irányított szervezeti változásokat szükséges végrehajtani, hasonlóképp az innovációt támogató tartalommal. Az innovációt támogató vállalati struktúrák, rendszerek, kultúra, illetve a szükséges tudás meglétében az innováció - adekvát menedzsmentkészségek mellett - hatékonyan megvalósulhat, így a nagyvállalat képessé válik a jelentős változásban lévő energiaipari környezethez való stratégiai adaptációra. Ezt a folyamatot mutatja be az 1 . ábra.

1. ábra

\section{Az innováció által indukált szervezeti változás (saját készítés)}

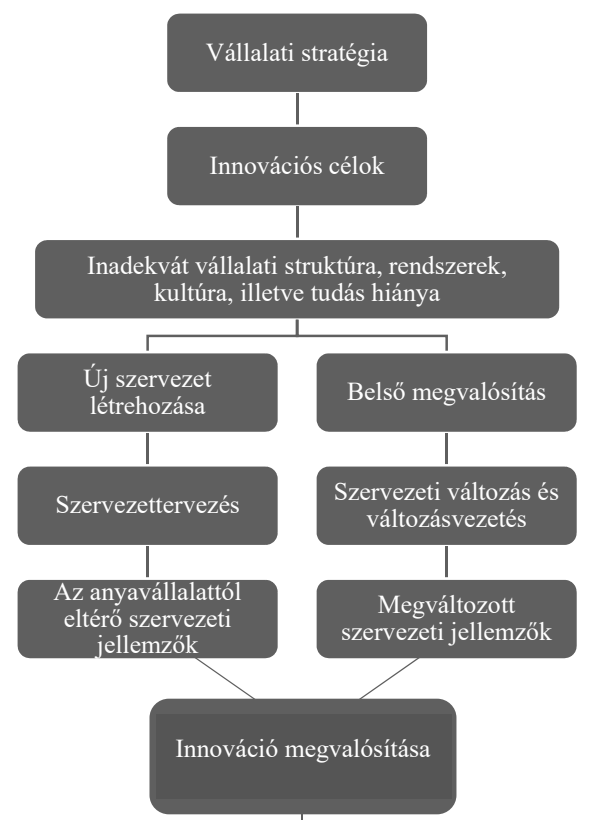

Megújulás, hosszú távú eredményesség

\section{Kontribúció és korlátok}

A tanulmány a magyar energiaszektor nagyvállalati szegmensének innovációmenedzsment-kihívásait, illetve az ezekre adható változásvezetési válaszokat mutatta be kvalitatív kutatás és a szakirodalom alapján. Fontos kiemelni, hogy kutatásunk nem tekinthető reprezentatív kutatásnak, kutatási eredményeink csak felszínes betekintést nyújtanak az energetikai nagyvállalatok innovációmenedzsment-kihívásaiba, így nem jelentenek közvetlenül implementálható, gyakorlati megoldást. Tanulmányunk célja, hogy párbeszéd alakuljon ki a kutatók és a vállalati szakemberek között, mely párbeszéd az innovációs célok hatékonyabb implementációját eredményezheti. Ehhez szeretnénk mi is hozzájárulni jelenlegi tanulmányunkkal.

\section{Felhasznált irodalom}

Adil, A. M. - Ko, Y. (2016): Socio-technical evolution of Decentralized Energy Systems: A critical review and implications for urban planning and policy. Renewable and Sustainable Energy Reviews, May 2016, 57, p. 1025-1037.

Alagoz, B. B. - Kaygusuz, A. (2016): Dynamic energy pricing by closed-loop fractional-order PI control system and energy balancing in smart grid energy markets. Transactions of the Institute of Measurement \& Control, May 2016, 38, 5, p. 565-578. 
Anadon, L. - Bunn, M. - Chan, G. - Chan, M.- Jones, C. Kempener, R. - Lee, A. - Logar, N.- Narayanamurti, $V$. (2011): Transforming U.S. energy innovation. Energy Technology Innovation Policy Research Group, Belfer Center for Social and International A airs, Harvard Kennedy School, Cambridge, MA (2011) In: Costa-Campi, M.T. - Duch-Brown, N. - García-Quevedo, J. (2014): R \& D drivers and obstacles to innovation in the energy industry. Energy Economics, November, 46, p. 20-30.

Antal Zsuzsanna - Dobák Miklós (2004): Vezetés és szervezés. Budapest: Aula Kiadó

Bakacsi Gyula (2004): Szervezeti magatartás és vezetés. Budapest: Aula Kiadó

Balaton Károly - Hortoványi Lilla - Incze Emma - Lackzó Márk - Szabó Zsolt Roland - Tari Ernő (2009): Startégiai menedzsment. Budapest: Aula Kiadó

Beer, M. - Nohria, N. (2001): Breaking the code of change. Boston: Harvard Business School Press

Bollino, C. A. - Madlener, R. (2016): Foreword to the Special Issue on "High Shares of Renewable Energy Sources and Electricity Market Reform". Energy Journal, 2016 Special Issue. 37, p. 1-4.

Chen, H. H. - Chen, S. - Lan, Y. (2016): Attaining a sustainable competitive advantage in the smart grid industry of China using suitable open innovation intermediaries. Renewable and Sustainable Energy Reviews, September, 62, p. 1083-1091.

Chikán Attila (2008): Vállalatgazdaságtan. Budapest: Aula Kiadó

Christensen, C. M. - Raynor, M. E. - McDonald, R. (2015): What Is Disruptive Innovation? Harvard Business Review, December, 93, p. 44-53.

Cohen, W. (2010): Fifty years of empirical studies of innovative activity and performance. In: B. Hall - N. Rosenberg (eds.): Handbook of the Economics of Innovation, Elsevier (2010) In: Costa-Campi, M.T. - DuchBrown, N. - García-Quevedo, J. (2014): R \& D drivers and obstacles to innovation in the energy industry. Energy Economics, November, 46, p. 20-30.

Costa-Campi, M.T. - Duch-Brown, N. - García-Quevedo, $J$. (2014): R \& D drivers and obstacles to innovation in the energy industry. Energy Economics, November 01, 46, p. 20-30.

Cullmann, A. - Nieswand, M. - Seifert, S. - Stiel, C. (2016): No differences in effciency between public and private utilities. DIW Economic Bulletin, May 2016, p. 233-238.

Csath Magdolna (2001): Stratégiai változtatásmendzsment. Budapest: Aula Kiadó

Csedő Zoltán (2006): Szervezeti változás és változásvezetés a folyamatos differenciálódás és integráció tükrében: az innovatív gyógyszeripar példája. Doktori $(\mathrm{PhD})$ értekezés. Budapest: Budapesti Corvinus Egyetem, Gazdálkodástani Doktori Iskola

Csizmadia Péter (2015): A szervezeti innováció és tudásfelhasználás mintái a magyar gazdaságban. Doktori értekezés. Budapest: Budapesti Corvinus Egyetem, Szociológia és Társadalompolitika Intézet
Dobák Miklós (2002): Szervezeti formák és vezetés. Budapest: KJK-Kerszöv

Dobák Miklós - Hortoványi Lilla - Szabó Zsolt Roland (2012): A sikeres növekedés és innováció feltételei. Vezetéstudomány, 43, p. 40-48.

Duncan, R. (1976): The ambidextrous organization: Designing dual structures for innovation. The Management of Organization Design, 1, p. 167-188.

Ergüden, E. - Çatlioglu, E. (2016): Sustainability Reporting Practices in Energy Companies with Topsis Method. Journal of Accounting \& Finance, Jul, p. 201-221.

Fejes József (2015): Innovációs kalandozások az elmélettől a stratégiáig/Innovation adventuring from theory to strategy. Vezetéstudomány/Budapest Management Review, 46, p. 58-69.

Greiner, L. E. (1972): Evolution and Revolution as Organizations Grow, Harvard Business Review, 50, p. 37-46.

Hámori Balázs - Szabó Katalin (2012): Innovációs verseny: Esélyek és korlátok. Budapest: Aula Kiadó

Hernádi Bettina (2012): Green Accounting for Corporate Sustainability. Club of Economics in Miskolc, TMP, 8, p. 23-30.

Høgevold, N. M. - Svensson, G. (2012): A business sustainability model: a European case study. Journal of Business \& Industrial Marketing, 27, p. 142-151.

Hortoványi Lilla - Szabó Zsolt Roland (2008): The impact of management practices on industry level competitiveness in transition economies. In: Milé Terziovski (ed.): Energizing Management through Innovation and Entrepreneurship. London; New York: Routledge, p. 55- 71.

Hortoványi Lilla - Balaton Károly (2016): A versenyképesség és az innováció vállalati szintű vizsgálata. Vezetéstudomány, 47, p. 38-45.

Lawrence, P. R. - Lorsch, J. W. (1967): Organization and Environment: Managing Di erentiation and lntegration. Boston: Division of Research, Graduate School of Business Administration, Harvard University In: Fejes József (2015): Innovation adventuring from theory to strategy. Vezetéstudomány, 46. p. 58-69.

Luthra, S. - Kumar, S. - Kharb, R. - Ansari, Md. F. Shimmi, S. L. (2014): Adoption of smart grid technologies: An analysis of interactions among barriers. Rennewable and Sustainable Energy Reviews, May, 33, p. 554-565.

March, J. G. (1991): Exploration and exploitation in organizational learning. Organization Science, 1/1, 2, p. 71-87.

Markard, J. - Truffer, B. (2006): Innovation processes in large technical systems: market liberalization as a driver for radical change? Res. Policy, 35, p. 609-625. In: Costa-Campi, M. T. - Duch-Brown, N. - García-Quevedo, J. (2014): R \& D drivers and obstacles to innovation in the energy industry. Energy Economics, 46, p. 20-30.

Mészáros Tamás (2010): Régi és új elemek a stratégiai gondolkodásban. Vezetéstudomány, 44, p. 2-12.

Nisar, A. - Palacios, M. - Grijalvo, M. (2016): Open organizational structures: A new framework for the energy 
industry. Journal of Business Research. November, 69, p. $5175-5179$.

OECD (2011): Fostering Innovation for Green Growth. Organisation for Economic Co-operation and Development, Paris In: Costa-Campi, M. T. - Duch-Brown, N. - García-Quevedo, J. (2014): R \& D drivers and obstacles to innovation in the energy industry. Energy Economics, November, 46, p. 20-30.

Parobek, J. - Paluš, H. - Kalamárová, M. - Loučanová, E. - Šupín, M. - Križanová, A. - Štofková, K. R. (2016): Energy Utilization of Renewable Resources in the European Union: Cluster Analysis Approach. BioResources, 11, p. 984-995.

Porter, M. E. (1980): Competitive advantage: Techniques for analysing industries and competitors. New York: The Free Press

Pugh, D. S. - Hickson, D. J. - Hinings, C. R. - Turner, C. (1969): The Context of Organization Structures. Administrative Science Quarterly, 14, p. 91-114. In: Fejes József (2015): Innovation adventuring from theory to strategy. Vezetéstudomány, 46, p. 58-69.

Ruiz-Abellón, M. d. C. - Gabaldón, A. - Guillamón, A. (2016): Dependency-Aware Clustering of Time Series and Its Application on Energy Markets. Energies, Oct, 9, p. 1-22.

Salies, E. (2010): A test of the Schumpeterian hypothesis in a panel of European electric utilities. In: J. L. Gaffard-
E. Salies (eds.): Innovation, Economic Growth and the Firm. New York: Edward Elgar Publishing

Sára Zoltán - Csedö Zoltán - Fejes József - Tóth Tamás - Pörzse Gábor (2014): Innovation management and innovation strategies - the role of corporate knowledge in innovative processes. Vezetéstudomány, 45, p. 42-48.

Schaeffer, G. J. (2015): Energy Sector in Transformation, Trends and Prospects. Procedia Computer Science, 52, p. 866-875.

Schumpeter, J. A. (1939): Business Cycles. New York: McGraw-Hill

Sull, D. N. (1999): Why Good Companies Go Bad. Harvard Business Review. July/August, 77, p. 42-48.

Taródy Dávid (2012): Formalizált rugalmasság - a kettős képesség kialakulása egy középvállalatban. Vezetéstudomány, 43, p. 49-60.

Teece, D. J. (2011): Dynamic Capabilities: A guide for managers. Ivey Business Journal, March/April, 75, p. 29-32.

Yin, R. K. (2003): Case study research. Design and methods. Thousand Oaks: SAGE Publications

Zavarkó Máté - Bertalan Zsolt - Sára Zoltán - Csedö Zoltán (2017): Innovation and Knowledge Management in the Energy Sector. Journal of Energy Technologies and Policy, 7, p. 45-53. 